Témoigner Témoigner. Entre histoire et mémoire

Getuigen Revue pluridisciplinaire de la Fondation Auschwitz

$121 \mid 2015$

Violences radicales en scène

\title{
Nikolaus Wachsmann. KL. Een geschiedenis van de naziconcentratiekampen
}

Amsterdam: De Bezige Bij, 2015

\section{Fabian Van Samang}

\section{(2) OpenEdition}

\section{Journals}

\section{Édition électronique}

URL : https://journals.openedition.org/temoigner/3760

DOI : $10.4000 /$ temoigner.3760

ISSN : 2506-6390

Éditeur :

Éditions du Centre d'études et de documentation Mémoire d'Auschwitz, Éditions Kimé

Édition imprimée

Date de publication : 1 octobre 2015

Pagination : 169-170

ISSN : 2031-4183

Référence électronique

Fabian Van Samang, «Nikolaus Wachsmann. KL. Een geschiedenis van de naziconcentratiekampen», Témoigner. Entre histoire et mémoire [Online], 121 | 2015, Online op 01 octobre 2016, geraadpleegd op 03 février 2022. URL: http://journals.openedition.org/temoigner/3760 ; DOI: https://doi.org/10.4000/ temoigner.3760

Ce document a été généré automatiquement le 3 février 2022.

Tous droits réservés 


\section{Nikolaus Wachsmann. KL. Een geschiedenis van de naziconcentratiekampen}

Amsterdam: De Bezige Bij, 2015

Fabian Van Samang

\section{RÉFÉRENCE}

Nikolaus Wachsmann, KL. Een geschiedenis van de naziconcentratiekampen, vertaald door Paul Heijman, Nannie Plasman, Jan Willem Reitsma, Pon Ruiter \& Frits van der Waa, Amsterdam: De Bezige Bij, 2015, 960 p.

1 Met KL. Een geschiedenis van de naziconcentratiekampen vraagt Nikolaus Waschsmann een grote inspanning van zijn lezer. Het vergt volharding en een doorgedreven discipline om de meer dan 850 pagina's tekst aandachtig door te nemen, met oog voor de haast 3500 voetnoten die verwijzen naar archieffondsen uit meer dan veertig landen en zo'n 1500 geraadpleegde historische werken. Maar wie zich de moeite getroost, zal niet ontgoocheld worden - KL is een lijvige, maar bijzonder gedegen, evenwichtige, verhalende en exhaustieve studie over het ontstaan, de groei en de ondergang van het NS-kampsysteem. 'De definitieve geschiedenis van het Duitse concentratiekampsysteem', noemde Timothy Snyder het boek in een vroege review (Wall Street Journal, 24 april 2015), en Keith Kahn-Harris prees de vaardigheid van de auteur om zowel de enorme omvang van het kampsysteem als de impact ervan op het individu te beschrijven (The Independent, 9 april 2015).

2 Wachsmann stapt in zijn studie in ieder geval af van het monolithische beeld als waren alle kampen van begin tot eind gelijkaardig. Hij schetst daarentegen een geschiedenis van discontinuïteit en permanente verandering. De kampen waren enorm verscheiden, wat onder meer blijkt uit de functionaliteit (het waren plaatsen van hechtenis, van beloofde 'heropvoeding', van dwangarbeid, van executie en van massamoord), de 
samenstelling van de kamppopulatie (politieke dissidenten, 'asocialen' en 'criminelen', verplicht tewerkgestelden en krijgsgevangenen, veroordeelden en 'raciale' opponenten) en de personele bezetting (politie of SS'ers, de geleidelijke uniformisering van het personeel naar het voorbeeld van Dachau, de evolutie naar professionele beulen en de uiteenlopende motieven die daaraan ten grondslag lagen). Wie terugblikt ziet de continuïteit van het kampsysteem van 1933 tot 1945; maar sinds de geboorte van de kampen waren tal van alternatieve sluipwegen, afwijkende koersen en andere dan de gekende horizonten mogelijk. Het portret dat Wachsmann de lezer voorhoudt is er één van een langzaam, organisch gegroeid netwerk van kampen, dat vorm kreeg door de interactie van creatief fanatisme aan de basis en geïntegreerde besluitvorming aan de top. Daarbij besteedt hij vooral aandacht aan de radicalisering en brutalisering van de SS, die bovenal voortvloeide uit de machtshonger van de Reichsführer-SS und Chef der deutschen Polizei, Heinrich Himmler. Die laatste zorgde ervoor dat de SS de kampen overnam, ze in haar politieke projecten inschakelde, gebruikte als een door vreselijke werkomstandigheden gekenmerkte arbeidsplaatsen en er de uitgemergelde, arbeidsongeschikte gevangenen uiteindelijk op industriële manier om het leven liet brengen.

3 Die visie is echter ook problematisch. Ze suggereert immers dat de judeocide voortvloeide uit een kampsysteem dat zich van een instrument van repressie gestaag ontwikkelde tot een instrument van volkerenmoord. Joden waren bijgevolg slechts één van de vele subgroepen die in de muil van de steeds dodelijker wordende kampen verdwenen. Maar het NS-beleid tegenover Joden was al vernietigend, lang voor ziektes, hongersnood en ontbering de (of minstens enkele) kampen tot moordinstrumenten voor Russische krijgsgevangenen omvormden. Daarvan getuigen de slachtpartijen die volgden op de Duitse invasie in Polen (september 1939), de verhoogde mortaliteit in de getto's in de eerste helft van 1941 en de massa-executies door de Einsatzgruppen in de Sovjet-Unie vanaf juli van hetzelfde jaar. Die facetten van het nazisme komen in Wachsmanns boek dan ook nauwelijks aan bod - niet enkel omdat ze niet het thema vormen van zijn studie, maar wellicht ook omdat zijn voorstelling van de in massamoord culminerende kamppraktijk moeilijk te verzoenen valt met het reeds gevormde moordbeleid. Anders geformuleerd: het lijkt er op dat het niet zozeer de Joodse bevolking was die opging in een almaar dodelijker wordend kampsysteem, maar dat de almaar efficiënter wordende kampen werden ingeschakeld in een reeds moorddadig anti-Joods beleid.

4 Precies omdat Wachsmann suggereert dat de genocidale praktijk gestalte kreeg door de concrete, feitelijke (en moeilijk te voorziene) omstandigheden in de kampen, kan hij ook moeilijk een plaats geven aan de NS-ideologie, de antisemitische beeldtaal, de raciaal gekleurde redevoeringen, de anti-Joodse sfeer die geruime tijd aan de moordpraxis vooraf ging. Immers, als de facts on the ground het doden van miljoenen mensen dicteerden, dan verliezen de slogans en de toespraken hun belang als uitingen van een gecentraliseerd, bewust nagestreefd en doeltreffend beleid. Net daarom is de rol van Hitler en zijn antisemitische discours in Wachsmanns relaas onduidelijk en onderbelicht. Hoewel de auteur in zijn register aangeeft (Hitler, Adolf: 'passim') dat het hele boek van Hitlers aanwezigheid is doortrokken, is het aantal concrete verwijzingen naar de kanselier erg beperkt. Dat hij als premier (en als staatshoofd) een rol van betekenis kon spelen, is duidelijk. Wachsmann verwijst daarvoor onder meer naar de machtsstrijd (1935) tussen Reichsstatthalter von Epp en de zijnen, die een aan normen gebonden staat wilden, en het toenmalige hoofd van de Beierse politie, Heinrich 
Himmler, die streefde naar de (in Michael Wildts woorden) constante 'ontgrenzing' van het kampsysteem. Hitler intervenieerde in Himmlers voordeel, verbood de vrijlating van gevangenen, breidde het contingent SS-bewakers uit, liet de uitrusting van de kampen door het rijk betalen en gaf gratie aan de moordenaars - waardoor hij de deur openzette voor een verregaande radicalisering (135-145). Maar voor het overige zijn de verwijzingen naar Hitler vaag en beperkt - het initiatief om Oostenrijkse Joden te laten oppakken 'leek afkomstig van Hitler zelf' (250), dat om gehandicapten met gifgas te doden kwam er 'vermoedelijk met steun van Hitler' (338), de toegenomen nadruk op dwangarbeid kwam er 'van hogerhand' (385) en Himmler leidde de medische experimenten op gevangenen, 'waarschijnlijk met de steun van Hitler' (600). Op die manier ontstaat een beeld van een organisatie zonder mentor, een moordpraktijk zonder ideologie en uit de omstandigheden voortvloeiende - eerder dan vooraf geselecteerde - slachtoffers. Toch blijft de vraag naar het verband tussen idee en praktijk, tussen staatsideologie en genocide, tussen irrationele haat en modern, weloverwogen moordmechanisme een zinvol denkspoor - een denkspoor dat door Wachsmann te weinig werd bewandeld. 